\title{
ПОЛІОМІЕЛІТ: НОВІ ВИКЛИКИ НА ШЛЯХУ ДО ЕРАДИКАЦІЇ
}

\author{
ДУ «Інститут епідеміології та інфекційних хвороб ім. Л.В. Громашевського НАМН України»
}

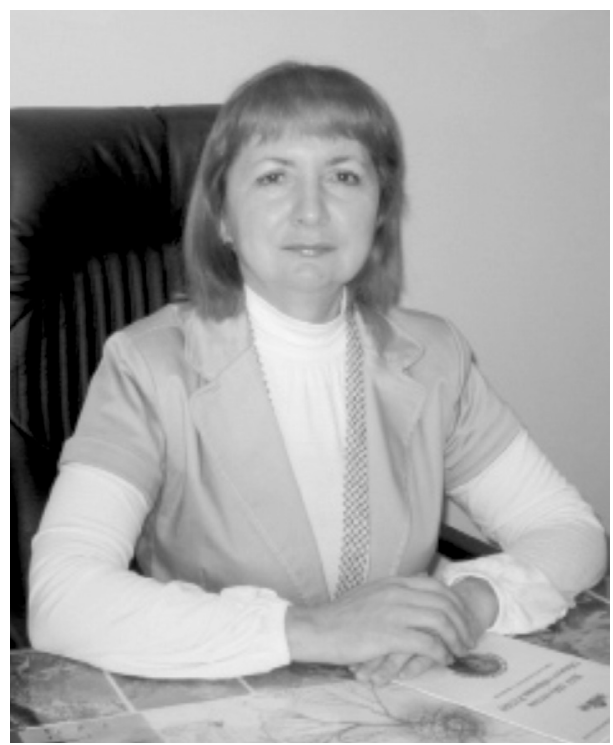

Незважаючи на очевидний прогрес у здійсненні Глобальної ініціативи по ліквідації поліомієліту (з 1988 р. кількість випадків поліомієліту скоротилася більш ніж на 99,9 \%, припинення циркуляції «диких» поліовірусів типів 1 і 3, зменшилася кількість ендемічних $з$ поліомієліту країн від 125 до 3 і т. д.), ряд невирішених питань залишаються, що перешкоджає досягненню кінцевої мети (тривала циркуляця «дикого» итаму поліовірусу 1 типу, фрормування вакциноспоріднених вірусів (VDPVs) і пов'язаних з ними ризиків, випадки вакцинасоційованого паралітичного поліомієліту (VAPP), прогалини в програмах імунізації деяких країн). У 2015 р. в Україні був спалах поліомієліту, спричинений циркулюючим вірусом VDPV1 (cVDPV1). Це сталося на тлі зниження планової вакцинації проти поліомієліту (наприклад, в 2014 р. - 44,7\%, за 7 міс. 2015 р. - 17,3\%). Це сприяло накопиченню неімунного прошарку серед дітей і формуванню VDPVs. У відповідь на спалах поліомієліту було проведено три раунди імунізації ОПВ. Проте їх рівні були недостатніми (відповідно 64,4, 71,7 і 80,7 \% порівняно з необхідними $95 \%)$. У той же час, результати спостереження показали високу ймовірність припинення циркуляції вірусу VDPV1.

Ключові слова: поліомієліт, ерадикація вірусу.
Поліомієліт відомий ще з часів єгипетських фрараонів і впродовж понад 3500 років залишався страшним тягарем для людства. Навіть зараз, згідно з останніми повідомленнями ВООЗ, летальність при паралітичному поліомієліті становить від 5 до 10 \% серед дітей та від 15 до 30 \% - серед підлітків і дорослих й переважно пов'язана з бульбарними ураженнями [1]. Лише в 20-му сторіччі було визначено вірусну природу цієї хвороби (поліовіруси трьох типів), а в 1950-х роках створено інактивовану (Джон Солк) та оральну (Альберт Себін) поліовірусні вакцини. Саме широке впровадження вакцинопрофрілактики стало тим дієвим заходом, який дозволив зупинити епідемію поліомієліту, що набула на той час загрозливих масштабів, а в подальшому в тих країнах, де вакцинація проводилася на належному рівні, знизити захворюваність до спорадичних випадків.

Виходячи $з$ досягнутих успіхів, Всесвітня асамблея охорони здоров'я в 1988 р. прийняла резолюцію щодо реалізації Глобальної ініціативи ерадикації поліомієліту, яка передбачала викорінення поліомієліту за рахунок припинення циркуляції «дикого» поліовірусу в масштабах світу з подальшим припиненням вакцинації. Досягти мети щодо ерадикції поліомієліту планувалося до 2000 р., однак у подальшому цей строк декілька разів переносився (2005, 2008, 2013, 2018 рр.) у зв'язку з виникненням проблем, які не були враховані при початковому прогнозуванні термінів реалізації необхідних заходів.

І хоча циркуляція «дикого» поліовірусу на земній кулі ще не припинена, натепер досягнуто надзвичайно великих успіхів у боротьбі з поліомієлітом. Так, на момент прийняття резолюції ендемічними вважалися понад 125 країн, щорічно реєстрували понад 350 тис. випадків паралітичного поліомієліту (близько 1000 випадків щоденно) та 16-20 млн осіб мали залишкові явища поліомієліту $[1,2]$. За час, що минув з початку реалізації програми ерадикації цієї інсрекції, 4 із 6 регіонів ВООЗ сертифріковані як вільні від поліомієліту - Американський (1994р.), Західно-Тихоокеанський (2000р.), Європейський (2002 р.) та Південно-Східний Азійський (2014р.). Припинена в глобальному масштабі циркуляція «дикого» поліовірусу типу 2: останній випадок зареєстровано в Індії в 1999 р., а у вересні 2015 р. було сертифріковано 
ерадикацію цього вірусу. Що стосується «дикого» поліовірусу типу 3, то останній штам було ізольовано в Нігерії 10 листопада 2012 р.

Незважаючи на досягнуті успіхи та той фракт, що натепер ендемічними залишаються лише 3 країни світу (Пакистан, Асрганістан, Нігерія), проблема поліомієліту не тільки не втрачає актуальності, а, навпаки, потребує ще більшої уваги у зв'язку, з одного боку, з припиненням циркуляції «дикого» поліовірусу на більшій частині земної кулі, необхідністю ретельного вірусологічного моніторингу, пов'язаного з ризиком його завозу на вільні території, з іншого боку, - 3 виникненням нових питань, що потребують вирішення.

Мета дослідження - визначити та проаналізувати проблемні питання щодо ерадикації поліомієліту у світі, епідемічну ситуацію 3 цієї інфекції в Україні та надати рекомендації щодо підтримки статусу України як території, вільної від поліомієліту.

За результатами власних досліджень і світових даних проаналізовано причини, що заважають завершити процес ерадикації поліомієліту на світовому рівні та становлять ризики щодо ускладнення епідемічної ситуації з поліомієліту в Україні.

Проаналізовано результати епідеміологічного нагляду за гострими в'ялими паралічами (ГВП)/поліомієлітом (1999-2015 рр.); статистичні звіти МОЗ України форма 5 «Виконання плану профрілактичних щеплень за рік» (2008-2015рр.); рекомендації 30-го засідання Європейського регіонального сертисрікаційного комітету [3]. У роботі використано бібліосемантичний, епідеміологічний, статистичний методи досліджень.

Динаміка циркуляції «дикого» поліовірусу у світі та проблема формування вакциноспоріднених варіантів вірусу.

«Дикі» поліовіруси. Сьогодні захворюваність на поліомієліт, спричинений «диким» поліовірусом, у світовому масштабі знизилася порівняно з 1980-ми роками майже на 99,9 \% (3 52795 випадків у 1980 р. до $74-$ у 2015 р.) (табл. 1).

Таблиця 1

Число випадків поліомієліту, спричинених «диким» поліовірусом, у динаміці

\begin{tabular}{|c|c|c|c|c|c|c|c|c|c|}
\hline \multirow{2}{*}{ Країна } & \multicolumn{9}{|c|}{ Роки } \\
\hline & 1980 & 2000 & 2009 & 2010 & 2011 & 2012 & 2013 & 2014 & 2015 \\
\hline Асрганістан & 880 & 120 & 38 & 30 & 81 & 46 & 12 & 28 & 20 \\
\hline Індія & 18975 & 265 & 756 & 43 & 1 & 0 & 0 & 0 & 0 \\
\hline Пакистан & 2980 & 199 & 89 & 144 & 198 & 74 & 98 & 306 & 54 \\
\hline Нігерія & 816 & 638 & 541 & 48 & 95 & 130 & 52 & 6 & 0 \\
\hline Загалом у світі & 52795 & 2971 & 1783 & 1349 & 716 & 293 & 396 & 359 & 74 \\
\hline
\end{tabular}

Тривалий час однією з найбільш проблемних серед ендемічних країн залишалася Індія. Так, в 1980 р. в Індії було зареєстровано 18975 випадків поліомієліту, спричиненого «диким» поліовірусом. За 20 років активної вакцинальної кампанії кількість випадків у цій країні знизилася до 265, а починаючи з 2012 р. і дотепер, такі випадки відсутні взагалі. Це дозволило вилучити Індію зі списку ендемічних країн. Слід відмітити, що починаючи з 2013 р., усі випадки поліомієліту, спричиненого «диким» поліовірусом, були етіологічно пов'язані лише з поліовірусом типу 1. Оскільки в 2015 р. в Нігерії не виділили жодного штаму «дикого» поліовірусу, були сподівання, що найближчим часом кількість ендемічних країн зменшиться до 2. Однак на 8 листопада 2016 р. у Нігерії зареєстровано вже 4 випадки поліомієліту, пов'язаних 3 «диким» поліовірусом типу 1 [4].

Вакциноспоріднені поліовіруси (VDPVs). На тлі вираженої динаміки щодо зниження циркуляції «дикого» поліовірусу зростає роль VDPVs як в етіології паралітичного поліомієліту, так і у віддалені термінів успішного завершення ерадикації поліомієліту. На початку реа- лізації Глобальної ініціативи ерадикації поліомієліту можливість фрормування VDPVs та пов'язаних з ним проблем до уваги не брали. У той же час, про можливість реверсії вакцинних поліовірусів у бік набуття нейровірулентних властивостей у процесі циркуляції говорилося багатьма дослідниками. За нашими даними, внутрішньотипової дифреренціації штамів поліовірусу (за френотиповими ознаками), виділених від людей (209 штамів) та 3 об'єктів довкілля (62 штами), 22,1 та 14,6 \% відповідно мали ознаки «проміжних» (між вакцинними та «дикими»). Ці віруси циркулювали в Україні в період 1982-1993 рр.

Перший задокументований спалах, спричинений VDPVs, мав місце на Карибському острові Hispaniola (2000-2001 рр.) і був етіологічно пов'язаний з поліовірусом типу 1 [5]. Однак, за результатами ретроспективних досліджень, першим слід вважати спалах у Польщі в 1968 р., спричинений поліовірусом типу 3. У зв'язку 3 цим ще в 2004 р. наголошувалося на тому, що активне формування VDPVs можливо і в умовах розвинутих країн $з$ помірним кліматом. 
VDPVs € генетично зміненою фрормою оригінального вакцинного вірусу Себіна, які відрізняються за нуклеотидними послідовностями ділянки геному VP1 для поліовірусу типів 1 та 3 більше ніж на $1 \%$ (або >10 nt замін), а для поліовірусу типу 2 - більше ніж на 0,6 \% (або >6 nt замін) [1]. При такому рівні генетичних змін ці віруси перестають бути атенуйованими та набувають властивостей нейровірулентності. За необхідності більш детального аналізу здійснюють повний аналіз геному [6]. У свою чергу, VDPVs поділяються на 3 категорії:

(1) циркулюючий VDPV (cVDPV), коли існує доказ передачі вірусу в популяції від людини до людині;

(2) VDPV, асоційований з імунодефіцитом (iVDPV), який виділяється від осіб з первинним В-клітинним або комбінованим імунодесріцитом (в окремих випадках екскреція вірусу продовжується до 10 років і більше);

(3) невизначений VDPV (aVDPV), який є клінічним ізолятом від осіб з невстановленим діагнозом імунодефріциту або ізолятом зі стічних вод при невідомому джерелі збудника інфекції.

У липні 2015 р. було переглянуто та більш деталізовано визначення cVDPV [7]. Поліовірус класифрікується як cVDPV у тих випадках, коли штами VDPV $€$ генетично пов'язані між собою та ізольовані:
- не менш ніж від 2 людей, які не мають родинних, побутових чи інших підтверджених контактів, коли б могла відбутися передача вірусу;

- із щонайменше 2 проб навколишнього середовища (проби відібрано з різних ділянок або з 1 ділянки з інтервалом не <2 міс.);

- від 1 людини та 31 проби з навколишнього середовища (у рамках епідеміологічного нагляду).

Також до cVDPV належить навіть єдиний ізолят із такими генетичними відмінностями, які свідчать про його циркуляцію протягом щонайменше 1,5 року.

Cаме cVDPVs становлять найбільшу небезпеку, оскільки їх фрормування відбувається на тлі зниження рівнів охоплення щепленнями, наявності неімунного прошарку населення, високого ризику переходу за таких умов до категорії персистуючих cVDPVs, тобто таких, що циркулюють понад 6 міс. Серед cVDPVs, які виділяли протягом останніх 15 років, превалювали віруси типу 2 (cVDPV2) (мал. 1) [8, 9]. Ураховуючи той фракт, що «дикий» поліовірус типу 2 не циркулює, починаючи 3 2000 р., таке активне фрормування cVDPV2s викликає занепокоєння щодо ризику їх укорінення на певних територіях та поступового набуття як генотипових, так i фенотипових властивостей «дикого» поліовірусу.

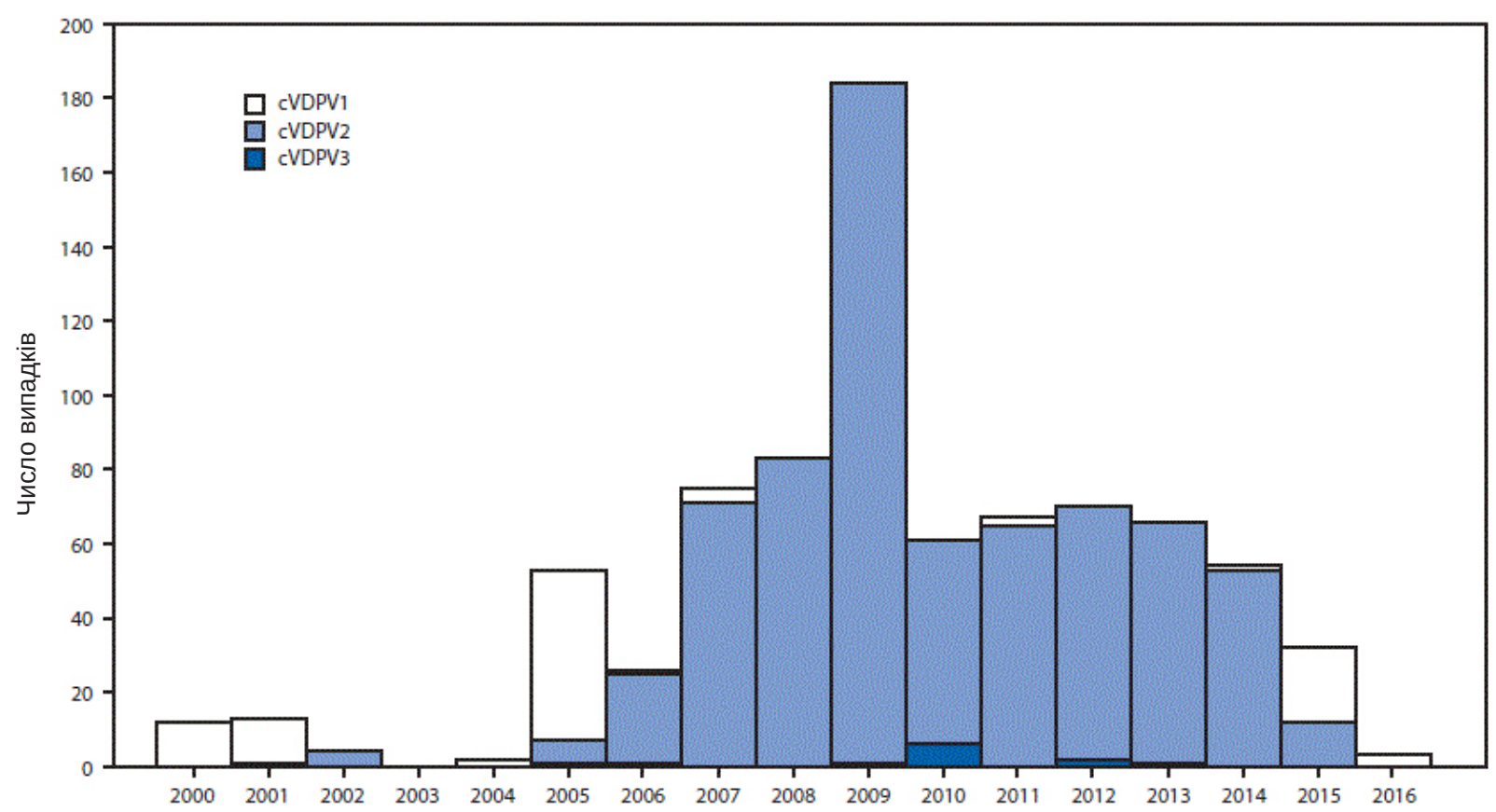

Мал. 1. Динаміка визначення циркулюючих вакциноспоріднених поліовірусів (cVDPVs) у світі з урахуванням їх серотипу (2000 р. - травень 2016 р.) [8].

Так, протягом 2014-2015 рр. у Гвінеї під час спалаху, який виник на тлі $42 \%$ охоплення 3 дозами оральної поліомієлітної вакцини (OПB), cVDPV2s було ізольовано від 13 осіб, зокрема 7 контактних [6]. За даними молекулярно-генетичних досліджень, вірус до моменту виявлення циркулював близько 2,7 року. За період 2015 р. 
- травень 2016 р. вдалося зупинити спалахи, пов'язані 3 cVDPV2, у Південному Судані й Афрганістані, а також знизити до низьких рівнів захворюваність в Пакистані та Нігерії.

Не меншу небезпеку з позиції наслідків для пацієнта становлять також cVDPVs й інших типів, зокрема cVDPV1s. Інтенсивність циркуляції саме цих вірусів значно зросла у 2015 р. порівняно з попередніми роками. 2 випадки були зареєстровані й в Україні (Закарпатська область). Віруси було ізольовано 30.06 та 07.07.2015 р. від дітей віком 4 роки та 10 міс. 3 клінічною картиною гострого в'ялого паралічу (ГВП). Віруси відрізнялися за VP1 на 2,2-2,9 \% від вакцинного штаму, що дало підставу вважати, що вони набули зазначених змін протягом 2,6 року циркуляції [6]. Цей спалах виник на тлі різкого зниження охоплення 3 дозами поліомієлітної вакцини дитячого населення (2014 р. - 44,7\%, на 01.08.2015 р. - 17,3\%).

Великі спалахи, спричинені cVDPV1s, у цей же період були зареєстровані в Лаосі (11 випадків поліомієліту, 25 контактних, приблизна циркуляція вірусу 3,5 року, рівень охоплення 3 дозами ОПВ - 88 \%) та на Мадагаскарі (10 випадків поліомієліту, 1 контактний, приблизна циркуляція вірусу - 3 роки, рівень охоплення 3 дозами ОПВ - 73 \%).

Що стосується iVDPV, то натепер у світі відомо близько 100 пацієнтів із первинним імунодефіцитом, від яких тривалий час спостерігається виділення таких вірусів [1]. У той же час дійсна картина щодо таких пацієнтів в популяції залишається невідомою. Після впровадження спостереження за iVDPVs, зросло й число таких виявлених випадків (з 8 - у 2014 р. до 21 - протягом 2015 р. - травня 2016 р.) [6]. За цей період усі виділені штами iVDPVs (окрім 2 штамів типу 3) належали до типу 2. Ці випадки були зареєстровані в 10 країнах. Також повідомлено про продовження виділення iVDPV2 від пацієнта (Великобританія) з первинним імунодефріцитом, яке триває протягом понад 29 років. Натепер вірус відрізняється за VP1 від вакцинного штаму на 16,6-16,7 \%. Кумулятивний розподіл iVDPVs за типами вірусу є таким: $66 \%$ - iVDPV2, по $14 \%$ - iVDPV1 та iVDPV3, 6 \% - одночасне виділення поліовірусу декількох типів. Таким чином, серед iVDPVs, як і серед cVDPVs, превалює поліовірус типу 2.

Протягом 2015 р. - травня 2016 р. aVDPVs були виділені в 19 країнах [6]. Віруси ізолювали, головним чином, від пацієнтів з ГВП та 3 об'єктів довкілля. На 31 серпня 2016 р. повідомлено про нові випадки ідентифрікації aVDPV2 у Конго, Єгипті, Індії, Кенії, Нігерії, Пакистані, Сенегалі та Сирії [10]. Також VDPV2s було виділено в Україні та Ємені, однак для остаточної класифікації цих вірусів ще потрібні додаткові дослідження.
Що стосується України, то перший штам aVDPV (типу 2) було ізольовано в 2014 р.

Згідно з останніми повідомленнями, за результатами вивчення повного геному штамів поліовірусу, що ізолювали в Нігерії в рамках епідеміологічного нагляду за поліомієлітом, простежено молекулярну еволюцію вакциноподібних штамів і розраховано час, необхідний для формування VDPV в умовах природної циркуляції [11]. Для поліовірусу типу 1 такі зміни відбуваються протягом 300 днів, для поліовірусу типу 2 - 210 днів, для поліовірусу типу 3 - 390 днів. Також підкреслюються значення рекомбінації як між поліовірусами, так і між поліовірусами й іншими ентеровірусами в формуванні VDPV. Таким чином, ці дані також демонструють найнижчу генетичну стабільність вакцинного поліовірусу типу 2 порівняно 3 вірусами інших типів.

Натепер все частіше використовуються методики моделювання молекулярних механізмів, які регулюють генетичні варіації і можуть допомогти в розумінні динамічних процесів, що стимулюють генетичну еволюцію вірусів. Такі методики пропонують використовувати і для дослідження переходу вакцинного поліовірусу в VDPV. Запропоновано стохастичну імітаційну модель, яка може бути використана для генерації гіпотетичних результатів на основі відомих механізмів генетичної різноманітності (штам Себіна типу 1 і штам Mahoney (вірулентний поліовірус типу 1)) [12]. Однак єдиним засобом, який дозволить протистояти формуванню VDPVs, є глобальний перехід на використання інактивованої поліомієлітної вакцини (ІПВ) з тривалим належним рівнем охоплення щепленнями.

Епідеміологічний нагляд за ГВП/поліомієлітом та епідемічна ситуація в Україні. Епідеміологічний нагляд за ГВП серед дітей до 15 років був запроваджений для належного вірусологічного обстеження всіх таких випадків з метою вчасного виявлення як «дикого» поліовірусу, так і будь-якого VDPV, та оперативного реагування на ситуацію. Ризик передачі «дикого» поліовірусу в кожній країні Європейського регіону оцінюється Регіональною сертифікаційною комісією. Залежно від комплексу чинників, які на нього впливають (рівень епідеміологічного нагляду, стан специфічного популяційного імунітету, інші чинники), він може бути визначений як низький, середній чи високий [3]. За відсутності циркуляції «дикого» поліовірусу та наявності належного рівня охоплення щепленнями в країні, індикаторний показник виявлення випадків ГВП серед дітей до 15 років, який свідчить про належну ефективність епідеміологічного нагляду, становить 1 на 100 тис. дитячого населення. За умов дії чинників, які підвищують ризик передачі «дикого» поліовірусу або VDPV, цей показник повинен становити 2-3 на 100 тис. 
У 2011 р. для України цей показник було підвищено до 2 на 100 тис. Це було пов'язано зі зниженням рівнів охоплення щепленнями дитячого населення, яке розпочалося з 2008 р. (мал. 2).

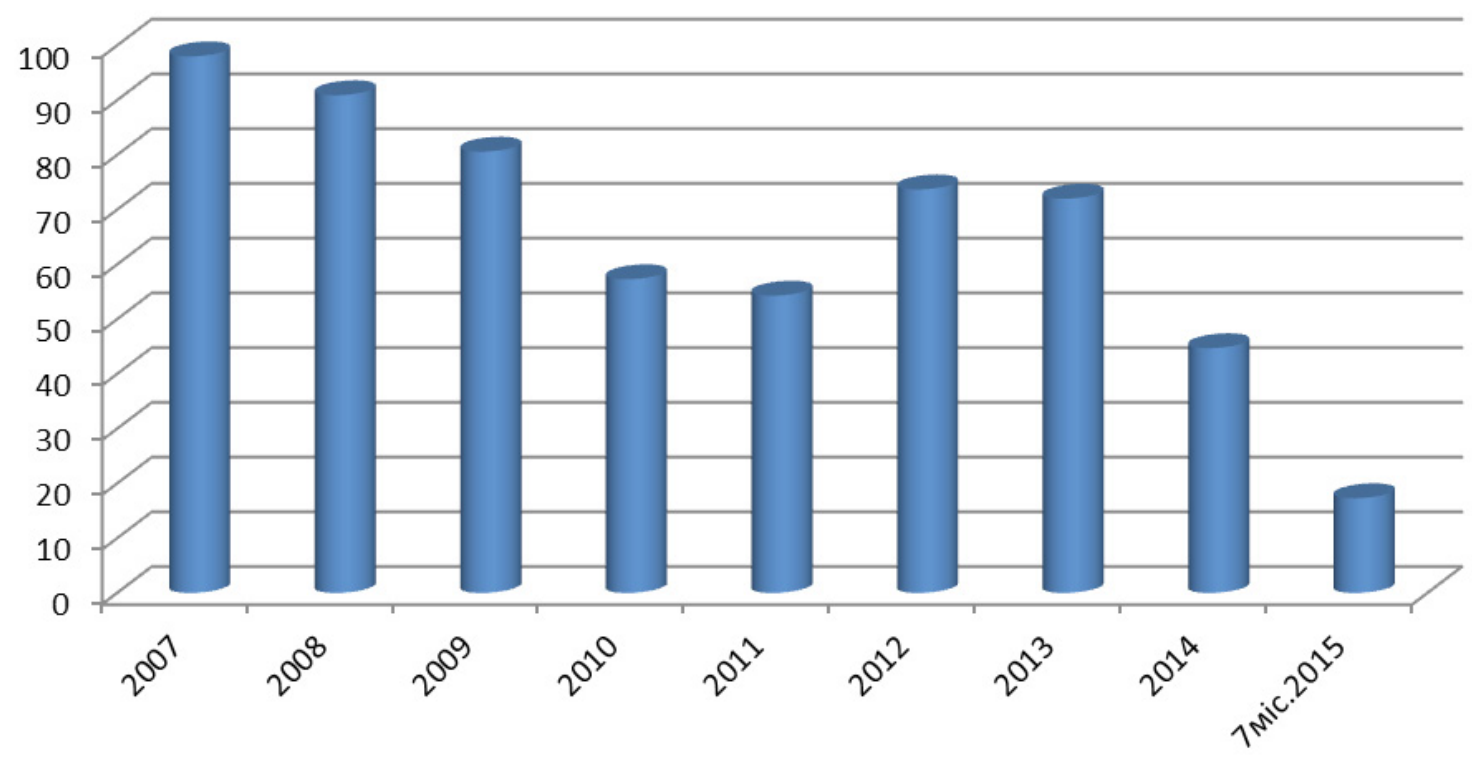

Мал. 2. Динаміка охоплення 3 дозами поліомієлітної вакцини дитячого населення України (у відсотках).

У матеріалах 7-го засідання Незалежної ради з моніторингу Україна відзначалась як єдина країна Європейського регіону, що мала статус високого ризику разом 3 країнами Африканського Рогу, Кенією, Лівією, Сомалі, Угандою, Єменом [13]. Тоді ж було рекомендовано в найкоротший термін виправити ситуацію щодо рівня охоплення 3 щепленнями і провести «підчищаючу» імунізацію тих дітей, хто не отримав за віком вакцинальний комплекс. На жаль, зазначені заходи проведені не були, що сприяло подальшому погіршенню епідемічної ситуації.

У зв'язку зі спалахом поліомієліту в Україні у 2015 р., натепер індикаторний показник для нашої країни повинен дорівнювати 3 випадки ГВП на 100 тис. дитячого населення. На 14.06.2016 р. (тобто менше, ніж за півроку) в Україні було зареєстровано 124 випадки ГВП (3,05 на 100 тис.) [14]. Для порівняння за цей же період часу аналогічний показник становив в Індії 11,44, Пакистані - 10,0, Афрганістані - 17,43, Нігерії - 24,12, Гвінеї - 20,75, Канаді - 0,19, Бразилії - 0,52, Румунії - 0,69, Греції - 0,86, Норвегії - 1,36, Польщі - 1,0, Грузії - 2,01, Казахстані - 2,45. Ці дані свідчать як про різну ефективність епідеміологічного нагляду в різних країнах, так і про набагато вищу поширеність випадків ГВП неполіомієлітної етіології в країнах Азії та Африки.

Окремого розгляду потребують випадки вакциноасоційованого паралітичного поліомієліту (ВАПП) та ГВП, пов'язаних у часі з вакцинацією ОПВ (мал. 3). Після впровадження в Україні епідеміологічного нагляду за ГВП/поліомієлітом стало можливим оцінювати дійсну ситуацію щодо ВАПП. В 1999 р. було зареєстровано 8 випадків ВАПП. На тлі припинення циркуляції «дикого» поліовірусу необхідно було прийняти заходи для запобігання виникненню таких випадків. Основним таким заходом могло бути впровадження ІПВ. Протягом 20002001 рр. було використано близько 400 тис. доз вакцини дітям з груп ризику щодо ВАПП, які були нами визначені на підставі епідеміологічного аналізу випадків ВАПП, що мали місце в Україні в попередні роки [15]. Уже в 2000 р. кількість випадків ВАПП зменшилася до 5, а в 2001-2002 рр. - до 2. У 2003 р. було зареєстровано лише 1 випадок ВАПП. У разі отримання 1 або 2 перших щеплення ІПВ, при подальшому переході на ОПВ жодна дитина не захворіла на ВАПП. Усі випадки ВАПП, починаючи з 2001 р., мали місце або при порушенні схеми імунізації (щеплення ОПВ замість ІПВ), або у невакцинованих дітей чи тих, які за віком усі щеплення отримували ОПВ. Протягом 2007-2009 рр. випадки ВАПП не реєструвалися, а кількість випадків ГВП, що збігалися в часі з прийомом ОПВ, у цей період знизилася до поодиноких (1-3 випадки) (мал. 3).

Однак на тлі стрімкого погіршення стану вакцинопрофрілактики в Україні знов почали реєструватися випадки ВАПП. Також, незважаючи на зменшення обсягу використання ОПВ, зросла кількість випадків ГВП, що співпадали в часі з прийомом ОПВ. У 2015 р. цей показник досяг 18 випадків, перевищивши показники всіх попередніх років. При цьому 17 із них були зареєстровані, починаючи з 29 жовтня, тобто на тлі турової вак- 
ПЕРЕДОВА СТАТТЯ

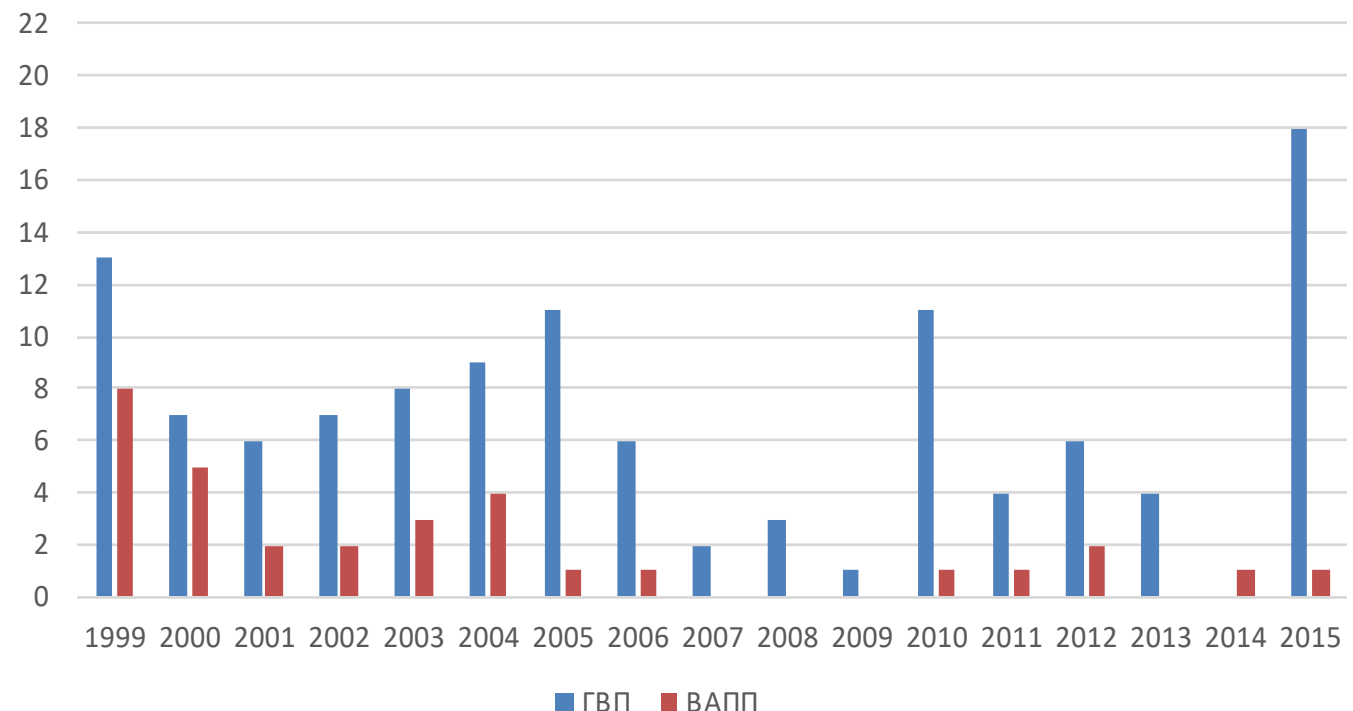

Мал. 3. Динаміка випадків ГВП, пов'язаних у часі з вакцинацією ОПВ, і ВАПП (1999-2015рр.).

цинації ОПВ (1-й тур було розпочато 19 жовтня), а в 2 дітей залишилися явища паралічу через 60 днів після їх початку. У той же час, у 2014 р. не було зареєстровано жодного такого випадку. Загальна кількість ГВП, зареєстрованих протягом 22 жовтня - 31 грудня 2014 та 2015 років, становила відповідно 21 та 40.

Серед пацієнтів з ГВП, розвиток яких співпав у часі з вакцинацією ОПВ, у 9 мало місце виділення вакцинних поліовірусів, зокрема у 3 дітей одночасно було ізольовано поліовірус двох типів, у 3 - трьох типів (табл. 2).

Таблиця 2

Виділення вакцинних поліовірусів від пацієнтів 3 ГВП, розвиток яких співпав у часі з вакцинацією ОПВ (2015 р.)

\begin{tabular}{|l|c|}
\hline \multicolumn{1}{|c|}{ Тип поліовірусу } & $\begin{array}{c}\text { Кількість } \\
\text { пацієнтів }\end{array}$ \\
\hline Поліовірус типу 2 & 2 \\
\hline Поліовірус типу 3 & 1 \\
\hline Поліовірус типу 1 + поліовірус типу 3 & 2 \\
\hline Поліовірус типу 2 + поліовірус типу 3 & 1 \\
\hline $\begin{array}{l}\text { Поліовірус типу 1 + поліовірус типу 2 + } \\
\text { поліовірус типу 3 }\end{array}$ & 3 \\
\hline Загалом & 9 \\
\hline
\end{tabular}

В 1 із цих дітей, в якого виділено поліовірус типу 2, залишкові явища паралічу зберігалися через 60 днів від їх початку. Ця дитина отримала ОПВ в 1 рік 5 міс. на тлі 2 щеплень ІПВ в анамнезі. ГВП розвинувся через 32 дні після щеплення. Згідно із заключною класифрікацією, цей випадок було віднесено до «інших неспецифічних неврологічних захворювань». Результати проведеного аналізу ще раз підтверджують отримані нами раніше дані щодо ролі вакцинних поліовірусів у розвитку ГВП у дітей, що співпадають за часом зі щепленнями ОПВ, і коли діагноз ВАПП неможливо поставити за відповідними критеріями $[16,17]$.

Заходи додаткової імунізації у відповідь на спалах поліомієліту в Україні, спричинений cVDPV1. 3 метою якнайшвидшого припинення циркуляції cVDPV1 було проведено 3 раунди імунізації ОПВ дітей віком від 2 міс. до 6 років (1-й і 2-й раунди) та від 2 міс. до 10 років (3-й раунд). Раунди проводилися відповідно 3 19.10.2015 по 06.11.2015 р., з 30.11.2015 по 18.12.2015 р. та з 25.01.2016 по 26.02.2020 р., а показник охоплення щепленнями дорівнював лише 64,4, 71,7 та 80,7 \% від загальної кількості дітей цільової групи. У той же час, оскільки турова імунізація спрямована на створення специсічного локального імунітету (у кишечнику вакцинованих ОПВ) у якомога більшої кількості дітей (принцип колективного захисту), рівень охоплення в кожному раунді повинен бути щонайменше 95 \%, чого, на жаль, досягти не вдалося. Однак завдяки цьому заходу вдалося підвищити загальний рівень охоплення 3 щепленнями серед дітей віком до 1 року до 90,1 \%, а серед дітей віком 1,5 року - до 95,8 \%. Що стосується адміністративних територій, то 10 із них мали рівень охоплення 3 щепленнями нижче 90 \% серед дітей віком до 1 року. Загалом під час турової імунізації принаймні 1 дозу ОПВ отримало 95,4 \% вікової групи від 2 міс. до 6 років та $92 \%$ - від 6 до 10 років.

Хоча за даними епідеміологічного нагляду за ГВП/ поліомієлітом та іншими ентеровірусними інорекціями можна з великим ступенем ймовірності припустити, що проведення турової імунізації призвело до припинення 
циркуляції cVDPV1, для збереження і підтримування Україною статусу вільної від поліомієліту території необхідним є відновлення в повному обсязі системи вакцинопрофрілактики з досягненням охоплення щепленнями за віком також тих дітей, хто їх не отримав у попередні роки.

Припинення вакцинації тривалентною ОПВ (тОПВ) та перехід на застосування бівалентної ОПВ (боПВ). Перехід на застосування бОПВ є першим етапом на шляху до глобального припинення використання живої поліомієлітної вакцини, що спрямовано в перспективі на припинення циркуляції вакцинних поліовірусів та, як наслідок, на усунення ризику фрормування VDPV [18]. Синхронне припинення використання тОПВ відбулося у світі 18 квітня - 1 травня 2016 р. [10]. Усі 155 країн і територій, що продовжували застосовувати ОПВ у програмах імунізації, повідомили, що вони припинили використання тОПВ. Рішення про перехід на бОПВ було прийнято у зв'язку з тим, що серед 721 випадку поліомієліту, спричинених cVDPVs за період 3 2006 р. по травень 2016 р., частка випадків, спричинених cVDPV2, склала понад 94 \%. А враховуючи той фракт, що «дикий» поліовірус типу 2 не циркулює у світі 3 2000 р., ВООЗ було вирішено знизити ризики виникнення поліомієліту, пов'язані з вірусом цього типу, за рахунок його вилучення з ОПВ.

Крім сказаного вище, цікавим є повідомлення про 4 випадки ВАПП у дитячому будинку, що виникли протягом 2 місяців 2010 р. і були пов'язані з вакциноподібним поліовірусом типу 2 [19]. Цей кластер випадків ВАПП $€$ унікальним, оскільки зазвичай вони є спорадичними. Будь-яких суттєвих змін в геномах виділених штамів не спостерігалося. В епідеміологічному відношенні при даному спалаху були розмиті межі між вакциноподібними і вакциноспорідненими поліовірусами, що є додатковим доводом про необхідність переходу на ІПВ у подальшому.

Жива вакцина бОПВ містить лише поліовіруси типів 1 і 3. Однак за умов застосування бОПВ до схем рутинної імунізації, де раніше застосовували лише ОПВ, повинно бути введено принаймні 1 дозу ІПВ, щоб забезпечити імунітет до поліовірусу типу 2.

\section{Висновки}

1. Не зважаючи на незаперечні успіхи щодо реалізації Глобальної ініціативи ерадикації поліомієліту (зниження захворюваності більш ніж на 99 \%, припинення циркуляції «диких» поліовірусів типів 1 та 3, зменшення кількості ендемічних країн із 125 до 3 тощо), залишається низка проблем, яка заважає досягненню кінцевої мети, зокрема триваюча циркуляція «дикого» поліовірусу типу 1, формування VDPVs та пов'язані з ними ризики, випадки ВАПП, прогалини в програмах імунізації окремих країн тощо.
2. Спалах поліомієліту, спричинений cVDPV1, виник у 2015 р. в Україні на тлі багаторічного зниження охоплення плановими щепленнями проти поліомієліту, що сприяло накопиченню неімунного прошарку серед дитячого населення та формуванню вакциноспоріднених поліовірусів.

3. Три раунди імунізації, проведені ОПВ у відповідь на спалах поліомієліту, за рівнем охоплення щепленнями цільової групи дітей не досягли адекватного рівня, однак за результатами епідеміологічного нагляду існує висока ймовірність припинення циркуляції cVDPV1.

4. Критична ситуація, що склалася в останні роки в Україні з вакцинопрофрілактикою, зокрема й поліомієліту, потребує її негайного вирішення. Для повернення Україні статусу країни з низьким ризиком передачі «дикого» поліовірусу в разі його завозу та збереження статусу вільної від поліомієліту території необхідним є відновлення в повному обсязі і на постійній основі рутинної імунізації та досягнення несприйнятливості тих дітей, хто не отримав щеплення за віком у попередні роки.

\section{Література}

1. WHO. (2016). Polio vaccines: WHO position paper - March, 2016. Weekly Epidemiological Record, 91(12), 145-168.

2. Sutter, R. W., Kew, O. M., Cochi, S. L., Aylward, B. (2013). Poliovirus vaccine - live. In S. A. Plotkin, W. A. Orenstein, P. A. Offit (Eds.), Vaccines: 6th ed. (pp. 598-645). Edinburgh, United Kingdom: Elsevier/Saunders.

3. WHO. (2016). Report of the 30th Meeting of the European Regional Certification Commission for Poliomyelitis Eradication (31 May to 2 June 2016). Copenhagen, Denmark.

4. WHO. (2016). Performance of acute flaccid paralysis (AFP) surveillance and incidence of poliomyelitis, 2016. Weekly Epidemiological Record, 91(47), 556-560.

5. Kew, O. M., Wright, P. F., Agol, V. I. (2004). Circulating vaccinederived polioviruses: current state of knowledge. Bull. WHO, 82(1). Retrieved from http://www.scielosp.org/scielo.php?script=sci_arttext\&pid $=$ S0042-96862004000100006

6. Jorba, J., Diop, O. M., Iber, J. (2016). Update on vaccine-derived polioviruses - Worldwide, January 2015-May 2016. MMWR, 65 (30), 763-769.

7. Global Polio Eradication Initiative (2015). Reporting and classification of vaccinederived polioviruses. - http://www. polioeradication.org/ Portals/0/ Document/Resources/ VDPV_ ReportingClassification.pdf

8. WHO. (2016). Update on vaccine-derived polioviruses worldwide, January 2015-May 2016. Weekly Epidemiological Record, 91(31), 365-375.

9. Introduction of inactivated poliovirus vaccine and switch from trivalent to bivalent oral poliovirus vaccine - worldwide, 2013-2016. (2015). MMWR. 64(25), 699-702.

10. WHO. (2016). Cessation of use of trivalent oral polio vaccine and introduction of inactivated poliovirus vaccine worldwide, 2016. Weekly Epidemiological Record, 91(36/37), 421-427.

11. Famulare, M., Chang, S., Iber J. (2015). Sabin vaccine reversion in the field: a comprehensive analysis of sabin-like poliovirus isolates in Nigeria. J. Virol., 90(1), 317-331. 


\section{ПЕРЕДОВА СТАТТЯ}

12. Ecale Zhou, C. L. (2016). S2M: A stochastic simulation vodel of poliovirus genetic state transition. Bioinform. Biol. Insights, (10), 81-95.

13. WHO: Global Polio Eradication Initiative (2012). 7th meeting of the Independent Monitoring Board. Weekly Epidemiological Record., $87(51 / 52), 509-512$

14. WHO. (2016). Performance of acute flaccid paralysis (AFP) surveillance and incidence of poliomyelitis, 2016. Weekly Epidemiological Record, 91(36/37), 427-432.

15. Задорожна, В .І., Фролов, А. Ф., Зубкова, Н. Л. (2012). Поліомієліт: імунопрофрілактика та її вплив на еволюцію епідемічного процесу. К.: ДІА.

16. Мойсеєва, Г. В. (2002). Характеристика імунопрофрілактики поліомієліту в Україні та оцінка ефективності використання інактивованої поліомієлітної вакцини. Автореф. ... дис. канд. мед. наук. К.

17. Торбенко, В.В.(2001). Оцінка ефективності сучасного епідеміологічного нагляду за поліомієлітом в умовах його ерадикації. Автореф. ... дис. канд. мед. наук. К.

18. Orenstein, W. A. (2015). Eradicating polio: how the world's pediatricians can help stop this crippling illness forever. Pediatrics, 135(1), 196-202

19. Korotkova, E. A., Gmyl, A. P., Yakovenko, M. L. (2016). A cluster of paralytic poliomyelitis cases due to transmission of slightly diverged Sabin 2 vaccine poliovirus. J Virol., 90 (13), 5978-5988.

\section{POLIO: NEW CHALLENGES ON THE WAY TO ERADICATION}

V.I. Zadorozhna, O.M. Tsyganchuk

The L.V. Gromashevsky Institute of Epidemiology and Infectious Diseases

SUMMARY. Despite the undeniable progress on the implementation of the Global Initiative eradication of poliomyelitis (polio cases have decreased by over $99,9 \%$ since 1988, the cessation of circulation «wild» polioviruses types 1 and 3 , the number of polio-endemic countries had decreased from 125 to 3, etc.), a number of outstanding issues remain that prevents the achievement of the ultimate goal (the continued circulation of the «wild» poliovirus type 1, the formation of vaccine derived polioviruses (VDPVs) and associated risks, cases of vaccine associated paralytic poliomyelitis (VAPP), gaps in immunization programs of certain countries and others. In 2015 in Ukraine there was an outbreak of poliomyelitis caused circulating VDPV1 (cVDPV1). This happened against the backdrop of years of decline coverage planned vaccination against poliomyelitis (for example, in $2014-44.7 \%, 7$ months of $2015-17.3 \%)$. This contributed to the accumulation of non-immune interlayer among children and the formation VDPVs. In response to the polio outbreak was conducted three rounds of immunization by OPV. However, their levels were inadequate (respectively $64.4 \%, 71.7 \%$ and $80.7 \%$ compared with the required $95 \%)$. At the same time, the results of surveillance showed high probability of termination circulation cVDPV1.

Key words: poliomyelitis, eradication.

Отримано 16.09.2016 р. 